\title{
COMMON GRAMMATICAL ERRORS \\ IN THE USE OF ENGLISH AS A FOREIGN LANGUAGE: A CASE IN STUDENTS' UNDERGRADUATE THESES
}

\author{
Bambang Sugeng \\ Faculty of Languages and Arts Yogyakarta State University \\ email: ba_geng@yahoo.com
}

\begin{abstract}
This study aims to find out the multitude of students' grammatical errors in their undergraduate theses and the learning materials needed to counter this problem. The study was a survey involving 228 undergraduate theses from 28 English study programs from 17 out of the 34 provinces in Indonesia. Data analysis included grouping, counting, and ranking the data. The findings show that errors rank as follows: verb groups, finite verbs, subject-verb concords, predicates, concords of nouns, concords of numbers, clauses, passive voice, and word choices. The common-core grammar materials, which contain inter-lingual implications, are recommended to be used as a potential solution to improve the quality of undergraduate thesis writing for students of the English study program.
\end{abstract}

Keywords: inter-language, grammatical errors, common-core grammar

\section{KESALAHAN TATA BAHASA DALAM PENGGUNAAN BAHASA INGGRIS SEBAGAI BAHASA ASING: KASUS DALAM SKRIPSI MAHASISWA}

\begin{abstract}
Abstrak
Penelitian ini bertujuan untuk menemukan kesalahan tata bahasa dalam skripsi mahasiswa program studi bahasa Inggris dan menyarankan bahan pembelajaran yang dibutuhkan untuk mengatasi masalah tersebut. Penelitian berupa survei yang melibatkan 228 skripsi dari 28 program studi bahasa Inggris dari 17 provinsi di Indonesia. Analisis data meliputi pengelompokan, penghitungan, dan pengurutan data. Temuan penelitian menunjukkan bahwa kesalahan tata bahasa dapat diurutkan sebagai berikut: verb groups, finite verbs, subject-verb concords, predicates, concords of nouns, concords of numbers, clauses, passive voice, dan word choices. Bahan pembelajaran common-core grammar, yang mengandung implikasi inter-lingual, diusulkan untuk digunakan sebagai potensi pemecahan masalah untuk meningkatkan kualitas skripsi mahasiswa program studi bahasa Inggris.
\end{abstract}

Kata kunci: inter-language, kesalahan tata bahasa, common-core grammar

\section{INTRODUCTION}

Grammatical errors in undergraduate freshmen' writing are common despite their six-year encounter with English classes. Without referring to which province the writer of the following paragraph comes from, I must say that this is an extreme error example.
Here is an example from the data in the study:

"Thestudentisstudiesabout therelation between reading comprehension and structure forms. He will understands problem of sentence in understanding text in comprehension test. In this case he must be look at the result of the researchs about relationship between text and structure." 
This paragraph, consisting of three sentences, was written by a freshman in an English-based S-2 (graduate) department in which I was one of the staff members. The freshman was an S-1 English department graduate, who had completed a graduating paper as a final project in the S-1 (undergraduate) study program. The sentences contained grammatical errors of such magnitude that startled me greatly. Most of these were errors of the simple, basic types made by many Indonesian students of English as a foreign language - inter-lingual errors mostly caused by the interaction between Indonesian and English in the students' language repertoires (Schauer, 2009; Selinker and Gass, 2008).

Written forms

the researcher is deals

he can produces several words

his words understandable

This is not an isolated case. In the S-1 classes, simple errors such as found above are abound. School teachers, when they are asked to use their speaking and writing skills in various workshops or trainings, make basic errors which are similar in nature. In great numbers, errors made by our students and school teachers include use of language items such as punctuation, concord of subject-verbs, concord of pronouns, noun forms, verb forms, and tenses (Sugeng, et al: 2005). Curiosity arises as to what extent such grammatical errors occur in students' academic writing. This question has motivated the writer to investigate into the grammatical quality of the students' use of English as a foreign language in their terminal project of their study.

The grammar of a language is the symbolic, conventionalized rule of language use which shows relationships between forms and meaning (Trousdale and Gisborne, 2008: 2) and distinguishes between correct and incorrect expressions (Young, 1984:11). The grammar of a language carries at least four characteristics. First, grammar is prescriptive. It tells the user of the language how to use the language in a decent way. It is like rules of etiquette which become the starting point for people to interact. In any language use, one can always distinguish between "decent use" and "poor use" of the language. Second, grammar is meaningful. For one thing, the elements of grammar-like vocabulary itemshave meanings in their own right. They are like idiomatic expressions that are formed by the speakers of the language arbitrarily. The past tense, for an example of a grammatical item, carries the meaning that the event represented by the verb happens in the past. The use of the definite and indefinite articles carries meanings which often times are intricate and crucial. Third, the grammar of a language carries a number of functions. One function is called the ideational or representative function in which one uses a language to express one's interpretation of the world. Fourth, grammar is grounded in physical reality. Though the rules of grammar are mental phenomena, their conceptualization is grounded in the activity of the brain, which functions as an integral part of the body, which functions as an integral part of the world. 
The teaching of grammar in the language class has undergone varied emphases. In the far-gone past, a language lesson is a grammar lesson. The teacher comes into the classroom, a classical text in the hand, explains the subjects and predicates of the sentences, translates sentences or texts, and gives grammar exercises (Brown 2000: 15). At the present time, the teaching of grammar has been reduced to almost zero in the language classes. Grammar has been associated with such negative reputations that it has a bad name, is associated with a trivial insistence on niceties, is often presented through mechanical exercises, and deals with such fruitless learning as irregularities of forms and the memorization of seemingly endless paradigms of constructions (Langacker, 2008: 4; Young, 1984: 11). This is often worsened by class teachers' attitudes that teaching grammar is "sinful", useless, and against the doctrines of modern language teaching methodologies. Grammar teaching is simply wrong and must be avoided.

Some claim that the decline in students' grammar mastery is related to a particular use of language teaching methodology in the instructional processes. This seems to raise certain doubts as whatever approach is used in the language classroom, grammar is still part of the learning and teaching. Research shows that grammar instruction in language classes is useful for helping the learners to develop their communicative competences, albeit the never-ending dissenting opinions about it (e.g. Purpura, 2004; Swan, 2006; Thornbury, 2002; Zhang. 2009). The teaching of grammar is an inherent part of the teaching of language taking careful precautions that it must not interfere with the learners' motivation and convenience.

Properly speaking, grammar must still be an important part of a language class. Whether a curriculum or textbook is billed as functional, communicative, structural, or whatever, grammar and grammar sequencing is an issue (Brown 2000: 118). In a rather extreme manner, Jackson (2005: 4) states that grammar is an essential component of both spoken and written language and that language would not be language without grammar. In this relation, grammar teaching needs to take into account the characteristics of the classroom instruction. Among other components of the teaching-learning process, the student is one that is characterized by different language backgrounds. Different language backgrounds may carry in influences in students' learning which can be positive or negative (Schauer, 2009: 16). A positive influence (commonly referred to as transfer) will help with, while a negative influence (commonly referred to as interference) will disturb the learning of the target language. Citing Oller and Ziahosseiny (1970) concerning this matter, Brown (2000: 214) gives an example that, for students of English as a second language, English spelling seems to be more difficult for people whose native language uses the Roman script (French, Spanish, Indonesian) than for those whose native language uses nonRoman script (Arabic, Chinese, Japanese). In the same way, an Indonesian student, with at least one background language, will produce English sentences whose grammar is marked, slightly or greatly, by the grammar of the background language. This language background influence describes the fact that Indonesian students learning English apt to have difficulties specific to basic grammatical items of English.

This study is motivated by the intention to further investigate the common difficulties faced by Indonesian students in their use of English as a foreign language. A great number of studies has been done on the problems of students in academic writing (e.g. Abdalhussein, 
2015; Balewa, 2014; Ernawati, 2010) and produced results that may offer much information about various aspects of students' grammatical errors. The present study is yet another source of information of the matter in question that is intended to find out the multitude of students' grammatical errors in their final project paper and what kind of materials is needed to counter this problem.

\section{METHOD}

The study was a survey on lastsemester students' final project paper writing commonly referred to as "skripsi". The aim of the study was to find out the level of the grammatical quality used by advanced students of teacher-education institutions in their academic writing. The survey involved 228 "skripsi" papers taken from 28 English study programs of teacher training universities in 17 of the 34 provinces in the six big islands of Sumatera, Java, Kalimantan, Sulawesi,
Nusa Tenggara, Maluku and Papua.

From each study program, 10 papers were selected randomly, two each from the 2011 academic year to 2015. In seven study programs, the selected papers were not complete since the study programs had fewer than five graduating years. Grammatical errors were taken throughout the paper, mostly from chapter 1 to 5 . Notes were also made as additional data on the formats and contents of the papers. Raw data were analyzed and grouped into types of errors and explanation on their possible causes.

Data analysis procedure consisted of grouping, counting, and ranking. In the grouping step, wrong phrases or sentences were sorted into types of errors. In the counting step, the phrases and sentences in each type were manually counted by numbers. In the ranking step, the error types were ranked by frequencies of occurrence.

Table 1. Distribution of Origins of "Skripsi" Papers by Provinces, Numbers, and Percentages

\begin{tabular}{clcc}
\hline Number & Province & Number of Papers & Percentage \\
\hline 1 & North Sumatera & 10 & 4.4 \\
2 & West Sumatera & 8 & 3.5 \\
3 & Riau & 10 & 4.4 \\
4 & Jambi & 14 & 6.1 \\
5 & Bengkulu & 10 & 4.4 \\
6 & South Sumatera & 10 & 4.4 \\
7 & Lampung & 10 & 4.4 \\
8 & West Java & 26 & 11.1 \\
9 & Central Java & 20 & 8.8 \\
10 & East Java & 34 & 15.1 \\
11 & Bali & 10 & 4.4 \\
12 & West Kalimantan & 10 & 4.4 \\
13 & East Kalimantan & 8 & 3.5 \\
14 & West Nusa Tenggara & 10 & 4.4 \\
15 & East Nusa Tenggara & 10 & 4.4 \\
16 & Maluku & 16 & 7.1 \\
17 & Papua & 12 & 5.2 \\
\hline & Total & 228 & 100 \\
\hline
\end{tabular}

LITERA, Volume 15, Nomor 1, April 2016 


\section{FINDINGS AND DISCUSSION}

Regardless of their years of study, students had a low level of grammatical quality in their "skripsi" writing. Errors occurred in almost every sentence they made and observation tended to indicate that they were not conscious of their errors. As it had been expected, errors included basic grammatical forms that were most probably caused by interlingual processes. Below is a list of the grammatical errors with selected examples from the multitude of phrases and sentences in the data:

\section{Categorization}

The grouping of grammatical errors into the 10 categories above was done arbitrarily based on the assumption that occurrences of errors were initiated by the influence of the students' language backgrounds. Other studies used different categories for such errors; Abdalhussein (2015), for example used 6 categories while Balewa (2014) used 8. It was unavoidable that some categories could cover more than one type of errors or one error could be included into more than one category. For example, 'In Indonesia, English considered as ...' could be grouped into the finite-verb category or passive voice. In such a case, discretion was taken as to which one was selected along with the implication that this decision was used throughout the analysis. Category 10 (Others) was designed for errors that

Table 2. Grammatical Mistakes Found in the "Skripsi" Writing by Types and Percentages

\begin{tabular}{|c|c|c|c|}
\hline Number & Type & Example & Percentage \\
\hline 1 & Verb group & $\begin{array}{l}-\ldots \text { is studies about } \ldots \\
\bullet \ldots \text { will understands problem of ... } \\
\text { - This research was to considered ... }\end{array}$ & 15 \\
\hline 2 & Finite verb & $\begin{array}{l}\text {-... teacher known student understanding or not. } \\
\text { - Students already done to do English Examination. } \\
\text {-... english becoming a subject that compulsory in Indonesia }\end{array}$ & 14 \\
\hline 3 & $\begin{array}{l}\text { Subject-verb } \\
\text { concords }\end{array}$ & $\begin{array}{l}\text { - As Finocciaro in Brown }(2001: 8) \text { state, ... } \\
\text {-... the way teacher deliver lesson in teaching learning } \\
\text { process. } \\
\text { - The student who understand or not is same score. }\end{array}$ & 14 \\
\hline 4 & Predicates & $\begin{array}{l}\text {-... many students bored in learning, } \\
\text { - The students confused why they had to... } \\
\text { - The students very disappointed. }\end{array}$ & 12 \\
\hline 5 & $\begin{array}{l}\text { Concords of } \\
\text { nouns }\end{array}$ & $\begin{array}{l}\text {-... as many as score ... } \\
\text { - Procedure text is one of type of text. } \\
\text { - To cope with those kinds of problem, ... }\end{array}$ & 10 \\
\hline 6 & $\begin{array}{l}\text { Concords of } \\
\text { numbers }\end{array}$ & $\begin{array}{l}\text { - One of the language is English. } \\
\text { - Here are the table which show ... } \\
\text { - There was two test }\end{array}$ & 10 \\
\hline 7 & Clauses & $\begin{array}{l}\text { - According to Brown }(2001: 362) \text { that Grammar ... } \\
\text { - So that the students can understand well what they read. } \\
\text { - As Brown (1982:3) states that the ability to read is very } \\
\text { crucial. }\end{array}$ & 9 \\
\hline 8 & Passive voice & $\begin{array}{l}\text { - There were two problems which discussed in this study. } \\
\text {-... errors divided into four categories: ... } \\
\text {-... the writer was intended to analyze ... }\end{array}$ & 7 \\
\hline 9 & Word choices & $\begin{array}{l}\text { - Referring the statement above, } \ldots \\
\text { - In Indonesian, English is taught as ... } \\
\text { - In give evaluation, ... }\end{array}$ & 5 \\
\hline 10 & Others & $\begin{array}{l}\text { - The students were lack of vocabulary. } \\
\text { - Must be tought } \\
\text { - Base on the explaination above the writer ... } \\
\text {... }\end{array}$ & 4 \\
\hline
\end{tabular}


could be included into the first 9 , such as spelling and confused words.

As it is shown in Table 2, three most common errors are concerned with verb groups, finite verbs, and subject verbconcords. This is quite in line with what is stated previously about the three types of errors that are most difficult for students. In their writing, they need to be extra careful when they use constructions of these types. As apparent later, 'is studies about' contains an error of generalization whereby students generalize that thirdperson singular subjects must be followed by a singular verb. In a similar manner, the construction 'will understands problem of', the third-person singular subject must be followed by a singular verb ignoring the presence of the modal auxiliary 'will'. Meanwhile, a generalization process occurs in 'This research was to considered' in which students mistakenly assumed that the past tense form of the verbs should be used in a past-tense sentence.

The second group of categories (predicates, concords of nouns, and concords of numbers) also indicate the influence of the students' background languages in their English sentences. In the group of predicates, the students assume that the used verbs (interested, confused, and disappointed) are complete predicates. They seem to have the knowledge that the three verbs already carry full meanings. In the group of concords of nouns, interlanguage processes occur. The students are not aware that in English, unlike in their background language, nouns have concords with other parts of speech such as the determiners. In the same way, in the concord of numbers, students are not accustomed to using the correct concords between nouns and numbers.

The last three groups of errors are easier to describe as they are mostly related to sentence meanings. Among the three, the passive voice is apparently most difficult since the passive voice in English has a specific grammar rule which is highly different from that in their background language. Errors in word choices may be explained by the possibility that the students do not have enough practice in vocabulary use. Meanwhile errors in the group of others may show that students are not careful enough in using written English. It may also be suspected that students do not have enough practice in learning and using English in the written form.

\section{Common-core Errors}

By a common-core error is meant one that students make mostly because of influences from their language backgrounds, widely known as interlingual errors (Abdalhussein, 2015; Balewa, 2014; Ernawati, 2010; George, 1972; Dulay, et al., 1982) in language learning processes. 'The students very disappointed.' and 'So that the students can understand well what they read.' are two examples of this kind of errors. Another common-core error is caused by over-generalization which, in the traditions of language learning and teaching, are commonly referred to intra-lingual errors (Abdalhussein, 2015; Balewa, 2014; Ernawati, 2010; George, 1972; Dulay, et al., 1982). Errors of this type are represented by expressions as 'is deals', 'This study was to compared', 'As Brown (1982:3) states that the ability to read is very crucial.', and others. The data indicate that the majority of the grammar errors found in students' writing belong to this category. Many of these are simple errors that should not have been made by advanced students of English.

Both types of errors become the sources of students' difficulties in their use of English for writing. This is mostly caused by the fact that they have been influenced by their language backgrounds. At least in one of their background languages, the rules of grammar can be very different from those of English. The 
phrase 'the students very disappointed' was translated into 'mahasiswa sangat kecewa' in which a finite verb does not need to be present. Meanwhile, in 'is deals', there is over-generalization that the third-singular subject receives the singular verb. In the same way, 'This study was to compared', has undergone over-generalization that the use of the past tense in English requires the past-tense verbs in the sentence.

The significant role that prior experience in first-language acquisition plays in second- or foreign-language learning is well recognized (Brown, 2000: 212). In learning English, an Indonesian student, with at least one background language, will produce English sentences whose grammar is marked, slightly or greatly, by the grammar of the background language. This background-language influence can be positive or negative towards the learning process of the target language (Schauer, 2009: 16). A positive influence (commonly referred to as transfer) will help with, while a negative influence (commonly referred to as interference) will disturb the learning of the target language. Citing Oller and Ziahosseiny (1970) concerning this matter, Brown (2000: 214) gives an example that, for students of English as a second language, English spelling seems to be more difficult for people whose native language uses the Roman script (French, Spanish, Indonesian) than for those whose native language uses non-Roman script (Arabic, Chinese, Japanese).

Knowledge of inter-language can be a great advantage in the teaching of English in the language classroom. Selection of the material and technique of teaching can be based on the concept of language transfer and language interference for more effective and efficient instructional processes. This principle has been used by teachers, consciously or unconsciously, with a certain extent of success. Many of the language teaching methodologies have acknowledged the usefulness of the concept of language transfer and language interference in helping students studying foreign languages. Brown (2000: 214) mentions, for example, that syntactic contrasts between Arabic and English reduce error rates for Arabic students in learning English. In a similar manner, instructional material that is developed by considering the advantages of interlanguage will be very helpful for the students. For example, parts of speech, word orders, and tenses are useful items for the selection of instructional material for Indonesian students learning English. It is based on this conviction that common-core grammar can be a solution to help students improve their writing competencies.

\section{Common-core Grammar}

Common-core grammar, often referred to as minimum-requirement grammar (Sugeng, et al, 2005), is grammar instruction based on the comparison between English and Indonesian. This grammar consists of up to nine points of grammar that are problematic to Indonesian students due to the structural differences between English and Indonesian. These nine grammatical points become minimum requirements, meaning that students will be regarded as mastering the grammar if they do not make errors in these points. The minimum-requirement errors occur in the sentences in Column 3.

\section{CONCLUSION}

In the old days, there was a time when final project papers were written with the upmost care that there was hardly any grammar mistake in the manuscript. This was an ideal expectation since "skripsi" papers were written documents that needed to be high in quality and free from grammar mistakes. With the running of time, however, the quality of students' 
language use in writing has declined to the point of most alarming that efforts are needed to give solution to this problem.

The present study has provided another clue that is expected to add awareness of teachers and practitioners of the real needs of the students in being able to write high-quality 'skripsi' papers. Many have expressed concern about these deficiencies and such concern has been shared widely. Expectation to improve students' grammar mastery in the use of English is often doubled by the fact that most of the graduates of the English study programs will become school teachers. In the field, they will become models for their students in the use of the language.
The time has come to provide students with instructional material that will help them improve their writing competencies. The common-core grammar is one of the potential alternatives to do just this.

\section{ACKNOWLEDGEMENTS}

The writer feels deeply indebted to Prof. Dr. Burhan Nurgiantoro and staff for letting this article published. He also would like to express his gratitude for colleagues who have given him reference materials for the writing of this paper. He finally thanks all the librarians and personnel who have allowed him to borrow students "skripsi" papers as the source of date for the survey study.

Table 3. Common-core Grammar by Categories, Sub-categories, and Sample Sentences

\begin{tabular}{|c|c|c|}
\hline Categories & Sub-categories & Sample Sentences \\
\hline Concords & $\begin{array}{l}\text { masculine and feminine pronouns } \\
\text { singular and plural forms for verbs } \\
\text { and pronouns. } \\
\text { nouns and determiner }\end{array}$ & $\begin{array}{l}\text { My sister goes to school. He is in the first grade. } \\
\text { Things which interferes ---., A teacher want ---., } \\
\text { Tell the student to put their ---. } \\
\text { Many book, each trees, another music and this } \\
\text { houses }\end{array}$ \\
\hline Finite Verbs & $\begin{array}{l}\text { finite verb in simple sentence and } \\
\text { every main clause } \\
\text { finite and non-finite forms of the } \\
\text { verbs }\end{array}$ & $\begin{array}{l}\text { He happy., The man who I met tall, He shown } \\
\text { me a book. }\end{array}$ \\
\hline Tenses & $\begin{array}{l}\text { change of tenses from present to past } \\
\text { or from past to present for no good } \\
\text { reason }\end{array}$ & The students are ready. He taught the next step. \\
\hline \multirow[t]{2}{*}{ Verb Groups } & $\begin{array}{l}\text { correct forms of the verbs in a verb } \\
\text { group }\end{array}$ & She will gone., You must to study hard. \\
\hline & $\begin{array}{l}\text { verb forms for questions and negative } \\
\text { statements. }\end{array}$ & He does not allowing ---., Did he liked ---? \\
\hline Clauses & $\begin{array}{l}\text { sentence patterns } \\
\text { e.g. SVO, SVC, etc. } \\
\text { subject and a predicate in main clause } \\
\text { and sub clause }\end{array}$ & $\begin{array}{l}\text { There is a student goes to library. The man } \\
\text { wears a blue shirt is my father. }\end{array}$ \\
\hline \multirow[t]{2}{*}{ Articles } & $\begin{array}{l}\text { a/an or the or a similar determiner } \\
\text { before a singular countable noun. } \\
\text { a/an before an uncountable noun or a } \\
\text { plural countable noun. }\end{array}$ & $\begin{array}{l}\text { She put book on chair. } \\
\text { He gave me a useful information. }\end{array}$ \\
\hline & $\begin{array}{l}\text { a/an or the before the name of a } \\
\text { person, town, or country. }\end{array}$ & The Mary left for the Jakarta. \\
\hline \multirow[t]{2}{*}{ Coordination } & and, but, or & $\begin{array}{l}\text { She explains grammar, vocabulary, and how to } \\
\text { study. }\end{array}$ \\
\hline & both....and, either...or, neither...nor & $\begin{array}{l}\text { Both the teacher as well as the students are } \\
\text { present. }\end{array}$ \\
\hline
\end{tabular}

LITERA, Volume 15, Nomor 1, April 2016 


\section{REFERENCES}

Abdalhussein, M.H.F. 2015. “Grammatical Error Analysis of Iraqi Postgraduate Students' Academic Writing: The Case of Iraqi Students in UKM Dr. Mohammed Subakir: Universiti Kebangsaan Malaysia". International Journal of Education and Research Vol. 3 No. 6.

Balewa, A. T. 2014. "An Analytical Study of Errors in the Written English of Undergraduate Engineering Students, ATBU: a Case Study". Journal of Education and Practice, Vol.5, No.38.

Brown, H. D. 2000. Principles of Language Learning and Teaching. (4 $4^{\text {th }}$ Ed.). New York: Addison, Wesley, Longman, Inc.

George, H.V. 1972. "Common Errors in Language Learning" in Norrish, J. 1983. Language Learners and Their Errors. London: McMillan.

Dulay, H., Burt, M. and Krashen, S. D. 1982. Language Two. Oxford: Oxford University Press.

Ernawati, E. 2010. "Identifying Problems in Students' Final Projects Based on Scientific Guidelines". Jurnal Lingua Cultura, Vol. 4 No.2, 201-217.

Jackson, H. 2005. Good Grammar for Students. London: Sage Publications.

Langacker, R. W. 2008. Cognitive Grammar: A Basic Introduction. New York: Oxford University Press, Inc.
Purpura, J. E. 2004. Assessing Grammar. Cambridge: Cambridge University Press.

Schauer, G. A. 2009. Interlanguage Pragmatic Development: The Study Abroad Context. London: Continuum International Publishing Group.

Selinker, L. and Gass, S. M. 2008. Second Language Acquisition: An Introductory Course. (3 ${ }^{r d}$ Ed.). New York: Routledge.

Sugeng, B., Supriyanti, N., Nurcahyo, R. 2005. Peningkatan Penguasaan Tatabahasa Bahasa Inggris Mahasiswa Jurusan Bahasa Iinggris FBS UNY melalui Pendekatan 'Common Core' yang telah Dimodifikasi. (Research Report). Yogyakarta: FBS UNY.

Swan, M. 2006. 'Teaching Grammar-Does Grammar Teaching Work?' Modern English Teacher 15/2.

Thornbury, S. 2002. How to Teach Grammar (5 $5^{\text {th }} E d$.). Essex: Pearson Education.

Trousdale, G. and Gisborne, N. (Eds.). 2008. Constructional Approaches to English Grammar. New York: Mouton, the Hague.

Young, D. J. 1984. Introducing English Grammar. London: Hutchinson Education, Ltd.

Zhang, J. 2009. "Necessity of Grammar Teaching". International Education Studies 2/2: 184-187. 